\title{
DIE WAARDE VAN DIE OU TESTAMENT VOLGENS H.F. KOHLBRUGGE: DIE OU TESTAMENT AS GESAGVOLLE WOORD VAN GOD WAT CHRISTUS VERKONDIG ${ }^{1}$
}

\author{
A.H. Bogaards ${ }^{2}$ \\ ABSTRACT \\ THE VALUE OF THE OLD TESTAMENT \\ ACCORDING TO H.F. KOHLBRUGGE: THE OLD \\ TESTAMENT AS AUTHORITATIVE WORD OF \\ GOD THAT PROCLAIMS CHRIST
}

The great passion in the life of Hermann Friedrich Kohlbrugge (1803-1875) was to give Christ his rightful place in theology. This article deals with his strife for Christ in the field of the Old Testament with particular reference to his book Wozu das alte Testament? Kohlbrugge's presumption in this book is that only the New Testament teaches us the value of the Old Testament. Christ and his apostles provided the key to understand the Old Testament. The author consequently seeks an answer to the question of the authority and contents of the Old Testament in the New Testament. His conclusion is that to Christ and his apostles the Old Testament is the authoritative Word of God in which Christ prevails, contrary to the modern theology of his day which regarded the Bible as a Jewish book, a book without Christ.

\section{INLEIDEND}

Hermann Friedrich Kohlbrugge was 'n ware herder, juis omdat hy oor niks anders kon praat en wou praat as oor die groot Herder van die skape, Jesus Christus ons Here, nie. Kohlbrugge het maar net een Noot op sy snaar gehad: Christus. Om Christus weer sy regmatige plek in die teologie te gee — dít was sy groot lewensstryd. Daardie stryd het hy op verskillende terreine gevoer.

1 Oorspronklik gelewer as referaat tydens 'n seminaar van die Departement Ekklesiologie, Fakulteit Teologie, Universiteit van die Vrystaat, op 4 September 2003.

2 Dr. A.H. Bogaards, Gereformeerde Kerk Pretoria-Rooiwal, Posbus 113, Pyramid, 0120; Navorsingsgenoot, Departement Ekklesiologie, Fakulteit Teologie, Universiteit van die Vrystaat.

ahbogaards@spg.co.za; Tuisblad: http://home.spg.co.za/bogaards 
Kohlbrugge is sekerlik meer bekend vir sy stryd vir Christus op die terrein van die heiligmaking. In 'n preek oor Romeine 7:14 ("Want ons weet dat die wet geestelik is, maar ek is vleeslik, verkoop onder die sonde"), die preek wat hom beroemd (of berug) gemaak het, sê hy byvoorbeeld die wet is vir ons 'n lyk (Kohlbrugge 1992a:53). ${ }^{3}$ En 'n ent verder vermaan hy, met sinspeling op Psalm 24, "Werp julle heiligingskrukke ver van julle af weg. Daarmee sal julle nooit die berg Sion opkom nie" (Kohlbrugge 1992a:57).

Sulke uitlatings is dikwels deur sy teenstanders verkeerd begryp. Op grond daarvan is hy beskuldig dat hy 'n antinomiaan is, dit wil sê, dat hy 'n streep deur die wet en die dankbaarheid trek. Maar Kohlbrugge was nie anti-nomos (anti-wet, anti-dankbaarheidswerke) nie. Inteendeel, hy was proChristus en juis só pro-nomos (pro-wet) in die mees Bybelse sin van die woord. Want dit was sy diepste oortuiging dat alleen in en deur Christus die wet vervul word en dat die heiligmaking in die mens se lewe tot sy reg kom.

Wie die preek oor Romeine 7 onbevooroordeeld lees, kom tot die ontdekking dat Kohlbrugge beslis nie 'n streep deur die wet as reël van dankbaarheid trek nie. Wel wys hy dié beskouing af as sou die mens, met die wet in die hand, sy eie saligheid op 'n manier kon help bewerk. Uitdruklik verklaar hy dan daarop wat volgens hom die bedoeling van die wet enersyds is om die mens uit hulle paradys van Christelike doen en late te dryf. Andersyds wys hy daarop dat die bedoeling van die wet is om die mense van die sandgrond van hulle eie werke na die Rots Christus te jaag (Kohlbrugge 1992a:51).

Vir Kohlbrugge het dit daaroor gegaan dat ons in Christus geheilig is. In 1 Korintiërs 1:30 staan immers nie net dat Christus vir ons wysheid uit God en geregtigheid en verlossing geword het nie, maar ók dat Christus vir ons heiligmaking geword het. Kohlbrugge het in sy werke swaar die nadruk gelê op die toegerekende heiligheid, dat Christus se heiligheid ons toegereken en geskenk word, soos die Heidelbergse Kategismus (H.K. vr. 18, 60 en 61) ook leer. Kohlbrugge het op grond van Skrif en belydenis geweet van ' $n$ borgtogtelike heiligmaking, dat die heiligheid van ons Borg, Christus, ons toegereken word en dat ons daarom heilig is.

In hierdie artikel gaan Kohlbrugge en sy opvatting oor die heiligmaking egter nie onder oë geneem word nie. Kohlbrugge se stryd vir Christus op die terrein van die $O u$ Testament sal die onderwerp van aandag wees.

3 Alle vertalings en parafrases in Afrikaans is uit die oorspronklike tekste gedoen deur die skrywer. 


\section{RELEVANTE FLITSE UIT KOHLBRUGGE SE LEWE TEN OPSIGTE VAN SY STRYD VIR CHRISTUS OP DIE TERREIN VAN DIE OU TESTAMENT}

Kohlbrugge is op 15 Augustus 1803 in Amsterdam gebore en op 5 Maart 1875 oorlede. Hy is in die Hervormde Kerk gedoop. Sy moeder was Hervormd en sy vader Luthers. In 1809 het die gesin Kohlbrugge oorgegaan na die Herstelde Lutherse Kerk. Kohlbrugge was eers proponent in die Herstelde Lutherse gemeente, maar na sy afsetting in 1827 het hy algaande meer oortuig geword van die waarheid van die Gereformeerde leer, onder andere die leerstuk van die uitverkiesing. Op sy sterfbed het hy nog gesê: "Die Heidelberger! Die eenvoudige Heidelberger! Hou daaraan vas, kinders!" (Van Lonkhuijzen 1905:333). Vanaf 9 Mei 1848 tot sy dood was hy predikant van die Nederlands-Gereformeerde Gemeente in Elberfeld in Duitsland.

Onder andere het sy vader 'n groot invloed op hom gehad. Dit het Kohlbrugge altyd bygebly dat sy vader vir hom gesê het: "Moses is die beste persoon om my in te bring en rond te lei in my Koning se paleis" (1986:42). Met "Koning se paleis" bedoel hy die Bybel. In die voorberig van sy boek waarop hier onder gekonsentreer sal word (Wozu das alte Testament?) vertel Kohlbrugge dat sy vader twee maal vir hom gesê het: "As jy die vyf boeke van Moses verstaan, verstaan jy die hele Skrif” (1988:I). Reeds in sy ouerhuis is die Ou Testament aan hom voorgehou as sleutel tot die verstaan van die hele Bybel en is die waarde daarvan by hom ingeskerp.

In 1828 het hy na Utrecht gegaan om sy proefskrif te skryf. Dit sou handel oor Psalm 45. Vir so 'n Ou-Testamentiese onderwerp was Kohlbrugge deeglik toegerus. Hy was 'n kenner van Hebreeus, Aramees, Siries en Arabies. Die Septuaginta en die Joodse geskrifte soos die Targums hanteer hy in sy proefskrif met die grootste bekwaamheid.

Juis in die tyd waarin hy met die doktorale studie besig was, was hy lank siek. Hierdie beproewing sou egter ryk vrugte dra. In die geestelike krisis wat daarmee gepaard gegaan het, is Kohlbrugge — so getuig hyself (Kohlbrugge 1989:40) — deur die Here in die profesieë ingelei. Sy oë is daarvoor geopen dat die Profete van Christus getuig; en die Profete hou Hom nie maar net voor as deugdeleraar nie, maar as Borg wat die sondes van sy broers sou dra. En dan sê Kohlbrugge iets wat soos 'n goue draad deur die hele res van sy teologie loop: Toe het dit vir hom opeens duidelik geword waarom die apostels - eers deur die onderrig van Jesus self en toe deur die lering van die Heilige Gees - bulle so ywerig daarop toegelê het om Moses en die Profete te ondersoek, want in 
Moses en die Profete het bulle die hele raadsplan van saligheid en genade wat in Christus Jesus verskyn het, leer ken (Wichelhaus 1857:VIII).

Nadat hy gesond geword het, het hy sy proefskrif voltooi en - hoe kan dit eintlik anders - daarin verklaar hy Psalm 45 so dat dit handel oor Christus en sy bruid, die kerk. Hy verklaar dit dus nié soos geleerdes in sy dae gemeen het, naamlik dat dit slegs 'n Oosterse bruilofslied oor Salomo was nie (Donkersloot 1962:25).

Wáar kom Kohlbrugge aan hierdie Skrifuitleg? Wié het hom geleer om Psalm 45 so te verklaar? Dit spel hy in alle duidelikheid uit in sy proefskrif. Hy sê' 'n mens moet in die skool van die beste Leermeester, Jesus Christus, en sy apostels les ontvang in Skrifuitleg (Kohlbrugge 1995:125). Hulle het die sleutel gegee waarmee ons die heilige deur tot die geheimenisse kan open (1995:129). Daarom weet Kohlbrugge in sy soeke na die regte verklaring van Psalm 45 van net een pad: na die skool van Jesus, na die klaskamer van die Hebreërbrief. Kom, sê Kohlbrugge (1995:131), kom ons luister wat die outeur van Hebreërs - hy beskryf hom met nadruk as daardie deur God geïnspireerde (theopneustos) skrywer - oor Psalm 45 te sê het. En dan is Kohlbrugge se konklusie: Dáár, in die skool van Jesus en sy apostels, en met name in Hebreërs 1:8-9, leer 'n mens met absolute sekerheid dat hierdie Psalm oor die Messias gaan (Kohlbrugge 1995:139-140). Aan die Hebreërbrief spandeer Kohlbrugge (1995:137-141) vyf bladsye in sy proefskrif, want dit is vir hom 'n kroongetuie ten gunste van die Messiaanse karakter van Psalm 45.

Natuurlik was die professore in Utrecht glad nie ingenome met so 'n proefskrif nie. Hulle het Kohlbrugge se opvatting verouderd en onwetenskaplik gevind. In Kohlbrugge (1889:7) se eie woorde: "Dit het hulle smaakloos gevind”. Volgens Van Lonkhuijzen (1905:98; voetnoot) sou een van hulle gesê het: "Meneer, skryf 'n ander proefskrif, want dit sal 'n skande vir die Utrechtse Akademie wees, as iemand met so 'n proefskrif in die 19de eeu aan ons akademie 'n doktorsgraad behaal." Kohlbrugge se antwoord daarop was: "Professor, ek gaan nie 'n ander proefskrif skryf nie. Dan moet hulle my maar laat druip." Die proefskrif was egter so goed dat hy uiteindelik cum laude geslaag het. Op 4 Junie 1829 het hy sy doktorsgraad ontvang.

Maar Kohlbrugge het ook meer as net 'n doktorstitel vir sy besondere uitleg van Psalm 45 ontvang; 'n vrou het ook bygekom. Op die dag van sy promosie het Cato se grootmoeder en voog hulle die ja-woord gegee. Dit het só verloop: toe sy van Cato verneem dat Kohlbrugge Psalm 45 verdedig as psalm oor Christus en sy bruid, die kerk, het sy gesê as Kohlbrugge as doktor terugkeer, kan sy hom gelukwens en sê dat hulle maar mag trou, 
want as hy Christus en sy bruid so verdedig en hom daarvoor nie skaam nie, skaam sy haar ook nie vir hom nie (Kohlbrugge 1889:7).

In 1846 het Kohlbrugge sy Wozu das alte Testament? geskryf. Daarop word nou ingegaan.

\section{SY BOEK WOZU DAS ALTE TESTAMENT?}

\subsection{Kohlbrugge se inleiding tot die boek}

Kohlbrugge (1855:7) begin die inleiding tot sy Wozu das alte Testament? met die opmerking:

Dit is beslis nie ' $n$ onverskillige saak watter waarde' $n$ mens heg aan die boek wat gewoonlik Ou Testament genoem word nie.

Daarmee sê hy eerstens waaroor dit vir hom in hierdie geskrif gaan: oor die waarde van die "Ou Testament". Tweedens benadruk hy dit: Hierdie vraag na die waarde van die Ou Testament is beslis geen kleinigheid nie, maar in sy eie woorde - "'n saak van die hoogste betekenis vir tyd en vir ewigheid."

In enige wetenskaplike boek is die inleiding van groot belang. Daarin sien 'n mens hoe die skrywer te werk wil gaan, waarheen hy mik en waarteen hy mik.

Kohlbrugge (1855:7) gee eerstens 'n aanduiding van sy werkwyse, dit wil sê hoe by hierdie vraagstuk van die waarde van die Ou Testament wil beantwoord. Hy wil dit doen deur 'n sorgvuldige ondersoek van die boeke van die sogenaamde Nuwe Testament. Wat sê die Nuwe Testament van die Oue? Dit is met die oog op die oplossing van hierdie vraagstuk die angewese weg.

Dit is sekerlik 'n suiwer Bybelse siening: die Skrif self moet lig werp op die waarde van sy dele. In hierdie geval is dit die Nuwe Testament wat die mens moet leer wat die waarde van Moses en die Profete is. Met hierdie benadering hou Kohlbrugge vas aan die beginsel wat hy self reeds in sy proefskrif neergelê het, naamlik dat 'n mens in die skool van die beste Leermeester, Jesus Christus, en sy apostels les moet ontvang in Skrifuitleg (Kohlbrugge 1995:125). Hulle het die sleutel gegee, sê Kohlbrugge (1995:129). Christus en sy apostels moet ons leer wat die gesag en die inhoud, wat die waarde van die Ou Testament is. In die hele res van sy boek soek hy dan ook in die Nuwe Testament die antwoord en daar alleen.

Die teologie van Kohlbrugge kan saamgevat word in een frase: die mens 'n nul, Christus alles. Dit geld nie alleen ten opsigte van die mens se saligheid nie. Dit is ook van toepassing wanneer dit by Skrifverklaring kom. Van nature 
is die mens nie bekwaam tot Skrifverklaring nie. Daarom moet die hulpelose mens na die Nuwe Testament toe gaan, dit wil sê na Christus toe, om die Oue te verklaar. En die omgekeerde is vir Kohlbrugge ewe waar: deur die Ou Testament - wat eweneens die woorde van Christus is - na die Nuwe Testament. Daarom kan Kohlbrugge ook — in naspreke van sy vader — sê: "Moses is die beste persoon om my in te bring en rond te lei in my Koning se paleis."

Kohlbrugge laat hom in sy Skrifuitleg nie lei deur buite-Bybelse bronne nie, maar aan die hand van Jesus, dit wil sê, aan die hand van die Ou en Nuwe Testament, gaan hy na die Bybel toe. Egte Skrifverklaring is 'n saak van Sola Scriptura. Kohlbrugge het hom streng gehou aan die beginsel van Sacra Scriptura sui ipsius interpres (= die Heilige Skrif is sy eie verklaarder).

Kohlbrugge (1855:7) motiveer in sy inleiding tweedens die noodsaak van hierdie ondersoek. Dit word, verklaar hy, al meer en meer die oorheersende opinie dat die Wet en die Profete tot die ou tyd behoort en dat dit nie meer vir ons dae bindend is nie. Daar is mense wat die Ou Testament slegs as 'n Jodeboek sien. Met Jodeboek bedoel hy: 'n boek sonder Christus en sonder Christus-profesieë.

Uit sy proefskrif kan ons aflei wie hierdie mense is wat die Ou Testament slegs as Jodeboek sien, want sy proefskrif is veral toegespits op en gemik teen die akkommodasie-teorie van sy dae (Van Wijk 1985:34). Kohlbrugge (1995: 131-132) gee self 'n beskrywing van hierdie teorie: in die akkommodasieteorie word beweer dat die apostels in hulle verklaring van die Ou Testament heelwat verwysings via akkommodasie op Christus toegepas het, hoewel dit in profetiese sin nie oor Hom gaan nie.

Met akkommodeer word bedoel: maak pas. Volgens hierdie teorie het die skrywers van die Ou Testament volstrek nie aan Christus gedink nie. Inteendeel, die skrywers van die Nuwe Testament het vele plekke in die Ou Testament so verdraai en gemaak pas, dat dit op Christus pas, terwyl dit tog op Dawid en ander sien.

Derdens wys Kohlbrugge in sy inleiding daarop hoe die Skrifkritici van sy dae met hulle voorstelling van die Ou Testament beskaam word deur die voorstelling wat die eerste Christelike kerk oor die "Ou Testament" gehad het.

In hierdie verband verwys Kohlbrugge na die opvatting wat die gelowiges in Berea oor die Ou Testament gehad het. In Handinge 17:11 staan:

Hulle het die woord van Paulus met alle welwillendheid ontvang en elke dag die Skrifte (d.w.s. Ou Testament) ondersoek of hierdie dinge wat Paulus geleer het, so was. 
Uit daardie teks blyk vir Kohlbrugge $(1855: 8,10)$ dat hierdie eerste Christene geen ander Bybel gehad het as die sogenaamde "Ou Testament" nie. In daardie Bybel, in die Skrifte, het die gelowiges van Berea dieselfde evangelie van Christus gevind as wat aan hulle deur Paulus en Silas gepreek is. Die "Ou Testament" was vir hulle die toetssteen vir die prediking van Paulus en Silas (Kohlbrugge 1855:11). Hulle het gesoek na woorde van lewe en van saligheid by God en as hulle Moses en die Profete nie as God se bindende Woord beskou het nie, sou hulle nie daarin gesoek het nie, maar dit eerder opsy gesit en hulle alleen aan die woord van die apostels gehou het. Die apostels self het hulle egter ook steeds na die Ou Testament terugverwys. In Handelinge 17:2-3 staan immers:

Paulus het uit die Skrifte — die Ou Testament — gespreek en hy het die Skrifte uitgelê en hy het uit die Skrifte aangetoon dat die Christus moes ly en uit die dode opstaan.

Kohlbrugge (1855:10) laat hom skerp uit oor die godgeleerdheid van sy tyd wanneer hy opmerk dat die gelowiges van Berea sekerlik nie teologie en kritiek (Skrifkritiek) bestudeer het nie, maar hulle het wel soveel verstand en insig ontvang as wat nodig was om die ooreenstemming tussen hulle Bybel (Moses en die Profete) enersyds en die evangelie van die apostels van Christus andersyds te herken. Daarom vind Kohlbrugge dit 'n skande vir die Christene van sy tyd dat hulle niks meer van die Ou Testament wil weet nie.

Voordat Kohlbrugge by die vraag Wozu das alte Testament? kom, wil hy aan die einde van sy inleiding eers ingaan op die titels Ou Testament en Nuwe Testament. Kohlbrugge praat deurentyd van "die sogenaamde Ou Testament" en "die sogenaamde Nuwe Testament". Daaruit moes dit al duidelik geword het dat hy glad nie met dié name saamstem nie. Die benaming Ou Testament is afgelei uit 2 Korintiërs 3:14. Uit dieselfde hoofstuk (v. 6) is dan gemaklik die teenstelling "Nuwe Testament" gemaak (Kohlbrugge 1855:12-13). Kohlbrugge (1855:13-16) se besware kan in vier punte saamgevat word:

1. Daar is geen bewys daarvoor dat diegene wat die boeke van Moses en die Profete eerste versamel het, dit "Ou Testament" genoem het, en dat diegene wat die boeke van die evangeliste en die apostels versamel het dit "Nuwe Testament" genoem het nie.

2. Paulus noem die boeke van die "Ou Testament" nêrens anders so nie. Hy praat van "die Skrif", "die Skrifte", "die Heilige Skrif" en "Moses en die Profete". Ook haal hy hulle soos volg aan: "God sê", "Hy het betuig" en "die Gees sê". 
3. Dat Paulus verkeerd uitgelê word en dat hy heeltemal iets anders bedoel het, is baie duidelik. Toe die apostel sy briewe geskryf het, het daar immers nog geen Nuwe Testament - ten minste 'n versameling wat so angedui word - bestaan nie. Derhalwe kon die apostel nie gedink het aan die teenstelling wat sedertdien gemaak word nie.

4. Paulus is oortuig dat die "Ou Testament" in sy hele prediking vervat is. Hy beroep hom op die gesag daarvan en wie dit doen, kan so 'n leer onmoontlik oud en sy eie nuut noem.

Kohlbrugge (1855:13) sien 'n groot gevaar in die benaming "Ou Testament", want dit is natuurlik dat by die aanduiding "Ou Testament" die gedagte aan iets wat oud is, by die lees daarvan die oorhand het, en gevolglik aan 'n teenstelling gedink word van iets wat nuut is. Volgens hom (Kohlbrugge 1855:14) bedoel Paulus met die uitdrukking "Ou Testament" bloot dít: wie Christus nie in Moses en die Profete vind nie — vir hom is dit "oud", "Ou Testament".

\subsection{Watter waarde die "Nuwe Testament" aan die "Oue" heg}

\subsubsection{Inleidend}

In vyf afdelings laat Kohlbrugge vervolgens sien

1. wat die Joodse tydgenote van Christus (soos die Fariseërs), wat Christus nie as die Messias erken het nie, van Moses en die Profete gedink het en dat hulle die Messias daarin gevind het;

2. wat Joodse tydgenote van Christus (soos Simeon en Anna) en die apostels, wat Christus wel as die Messias erken het, van Moses en die Profete gedink het en dat hulle die Messias daarin gevind het;

3. hoe Christus self in die dae van sy omwandeling op aarde Moses en die Profete beskou het;

4. hoe die evangeliste (Matteus tot Johannes) Moses en die Profete beskou het; en

5. hoe die apostels en hulle medegenote (in Handelinge, die briewe van Paulus, ens.) van Moses en die Profete gebruik gemaak het.

Kohlbrugge bewys dan uit die Nuwe Testament dat al vyf hierdie groepe Moses en die Profete gesien het

1. as gesagvolle Woord van God; en

2. as Woord van God wat die Messias of die Christus as inboud het. 
3.2.2 Wat die Joodse tydgenote van Christus (soos die Fariseërs), wat Christus nie as die Messias erken het nie, van Moses en die Profete gedink het en dat hulle die Messias daarin gevind het

Ook die Joodse tydgenote van Christus, wat Christus nie as die Messias erken het nie (bv. die Fariseërs) - ook hulle het Moses en die Profete as die gesagvolle Woord van God aanvaar. Hulle het die Skrifte in sy geheel as die Woord van God beskou. Dít, sê Kohlbrugge (1855:19-20) dan, doen vele Christene nie. Inteendeel, baie Christene meen dat die Bybel nie die Woord van God is nie, maar dat die Woord van God in die Bybel staan. Hierdie beskouing sien Kohlbrugge net as 'n verskoning waardeur hierdie Christene vir hulleself vrye speelruimte maak om slegs dit as die Woord van God te beskou wat hulle met hulle rede (verstand) in ooreenstemming kon bring. En dan beklemtoon hy die Jode het dít níe gedoen nie.

Daarmee sê hy dat nie eens die Jode wat nie in Christus geglo het nie, so met hulle Bybel omgegaan het soos hierdie Christene nie. Inteendeel, die Jode het die Skrifte hoog aangeslaan. Hulle het dit beskou as boek waarin die weg tot die ewige lewe aan hulle voorgehou word. Vir hierdie stelling beroep Kohlbrugge (1855:20) hom op wat Jesus self van die Jode sê — Jesus wat tog weet wat in elke mens se hart omgaan. Want in Johannes 5:39 (vgl. ook Luk. 10:25-28) sê Jesus vir die Jode: "Julle meen dat julle in die Skrifte die ewige lewe het".

Kohlbrugge gaan tweedens in op die vraag wat die ongelowige Jode in Moses en die Profete gevind het. Die antwoord uit die Nuwe Testament is dat die Geskrifte vir hierdie Jode die Messias as inhoud gehad het. Hy haal verskillende voorbeelde aan om dit te bewys:

- Die Jode het nit hulle Bybel geweet dat die Messias in Betlehem gebore son word. Wanneer Herodes (Mat. 2:1-6) by die owerpriesters en die skrifgeleerdes navraag doen waar die Christus gebore sou word, antwoord hulle hom: In Betlehem. En die antwoord vind die Jode in die profeet Miga (5:1). En dan maak Kohlbrugge (1855:22) daarby die skerp opmerking dat baie Christelike teoloë, wat die voorspellings nie glo nie, seker sal wonder hoe hulle dit uit Miga kon aflei, want die Rabbyne se reëls van Skrifuitleg was toe nog nie bekend nie; ten minste, die Targum spreek nie ten gunste van hierdie verklaring nie.

- Nog 'n voorbeeld (Kohlbrugge 1855:23): die Jode het uit bulle Bybel geweet dat die Messias die Seun van Dawid sou wees. Die gewone volk het dit, volgens Johannes 7:42, uit die Skrif uit afgelei. Ook die Fariseërs het dit geweet, want op Jesus se vraag wat hulle van die Christus dink, wie se Seun Hy is, antwoord hulle eenstemmig: "Dawid s'n" (Mat. 22: 
42). Hieruit maak Kohlbrugge die afleiding dat 2 Samuel 7 en meer plekke in die Profete en in die Psalms deur die Jode in hulle skole en in hulle sinagoges Messiaans uitgelê is. Daarom is dit nie vreemd dat vele uit die volk met soveel beslistheid kon sê: "Het die Skrif nie gesê dat die Christus uit die geslag van Dawid kom nie?" Daarom is dit eweneens nie snaaks dat die kinders by die intog van Jesus in Jerusalem uitgeroep het: "Hosanna vir die Seun van Dawid!" nie (Mat. 21: 9, 15). Nie alleen die geleerde Jode nie, maar ook die gewone volk en selfs die kinders lê die Skrifte Messiaans uit.

Hier kan terloops verwys word na wat uit buite-Bybelse bronne oor die Jode se Messiaanse beskouing van die Ou Testament afgelei kan word. A.H. Edelkoort (1941:307) skryf in verband met Psalm 2 dat die Midrash op die Psalms, die Babiloniese Talmud en die Kabalistiese Joodse boek Sohar almal Psalm 2 op die Messias betrek. In dié rigting wys ook 'n Talmud-traktaat wat Psalm 2:1-3 aanhaal en daarby sê dat in die tyd van die Messias die proseliete teen God en sy Messias sal rebelleer. By vers 7 en volgende twyfel die Rabbyne nie daaraan dat dit oor die Messias, die Seun van Dawid, spreek nie. Selfs geleerdes soos Kimchi (1105-1170) en Jarchi — so skryf Hengstenberg (1973:43) — erken dat dit die oorheersende opinie onder hulle voorvaders was. ${ }^{4}$

Dit is diep tragies! Óók die Jode wat Christus nie geken het of wou aanvaar nie, óók hulle het geweet en geglo dat Moses en die Profete die Messias as inhoud het, maar vele teoloë in ons tyd glo dit nie. Maar, as die teoloë swyg, sal die klippe dit uitroep. En "Uit die mond van kinders en suigelinge het U vir U lof berei" (Mat. 21:16); "Hosanna vir die Seun van Dawid! Geseënd is Hy wat kom in die Naam van die Here" (Mat. 21:15).

\subsubsection{Wat Joodse tydgenote van Christus (soos Simeon), wat}

Christus wel as die Messias erken het, van Moses en die Profete gedink het en dat hulle die Messias daarin gevind het

Een — veelseggende — voorbeeld is hier genoeg: Simeon. In Lukas 2:25 staan van hom geskrywe: Hy het die Vertroosting van Israel verwag (vgl. Jes. 40:1; 49:13; 51:12; 54:11; Hag. 2:8). Met hierdie uitdrukking gee die evangelis

4 Die Talmud is naas die Ou-Testamentiese boeke die belangrikste geskrifte van die Jodedom. Dit het ontstaan uit die mondelinge oorlewerings rondom die wet van Moses ná die Babiloniese ballingskap en is ongeveer 500 n.C. afgesluit. Die Targums is die Aramese parafrases van die Ou Testament en dit is nie voor 500 n.C. afgesluit nie. Die Midrash is die naam vir die Skrifverklarings van die Rabbyne. Dit het begin rondom die Christelike jaartelling en is in die vyfde eeu n.C. voltooi. 
duidelik te kenne dat Simeon die boeke van Moses en die Profete as die onbedrieglike Woord van God beskou het en dat hy die vervulling van alle troosryke beloftes daarin as baie naby beskou het (Kohlbrugge 1855:37). Simeon was so vol van hierdie geloof dat hy nie kon ophou bid dat hy die vervulling van hierdie beloftes mag belewe nie. En, sê Kohlbrugge (1855:3738), iemand wat só bid, bewys daarmee dat hy die woorde van Moses en die Profete as die waaragtige woorde van God beskou. En, vervolg hy (Kohlbrugge 1855:37-38), Simeon het begeer om die Gesalfde van die Here met sy eie oё te aanskou. Dit bewys dat hy die Skrifte, onder andere Jesaja 33:17 — "Jou oë sal die Koning in sy skoonheid aanskou" - Messiaans, as van toepassing op Jesus, verstaan het.

Kohlbrugge (1855:38) wys onder andere ook nog op die woorde van Simeon:

Nou laat U, Here, u dienskneg gaan in vrede volgens u woord, omdat my oё u heil gesien het, wat U berei het voor die oë van al die volke (Luk. 2:29-30).

Daaruit is dit vir Kohlbrugge duidelik dat Simeon ook Jesaja 52:10 geken en Messiaans verklaar het:

Die HERE het sy heilige arm ontbloot voor die oë van al die nasies, en al die eindes van die aarde sal sien die heil van onse God.

Dit is diep aangrypend wat Kohlbrugge van die daad van Simeon sê. Simeon het die Kind in sy arms geneem en God geloof. Want, sê Kohlbrugge (1855:38), daarmee sê Simeon die boeke van Moses het vir hom in vlees en bloed oorgegaan na die Woord van die lewende God. Simeon staan met die vervulde Ou Testament, met die inhoud van die Ou Testament, in sy arms. Voor sy oë sien hy in vlees en bloed dat God se Woord waaragtig en betroubaar is. En hy erken dit deur God te prys. Al die Ou-Testamentiese tekste wat hy aanhaal, sien hy vervuld in die vleesgeworde Woord.

Hoe kan dit wees dat teoloë in ons tyd die Messias nie meer in die $\mathrm{Ou}$ Testament sien nie? Hoe sien Simeon Hom dan wel? Hoe sien die ou Simeon Christus wel in die Skrifte, ook toe Christus nog nie eens daar was nie en nog nie in sy hande was nie? Waar kom hy aan sy Messiasverwagting, sy verwagting van die Vertroosting van Israel? Dit verduidelik Kohlbrugge (1992b:279-280) in 'n preek: Dit was uit die Heilige Gees. Daarom staan daar in Lukas 2:25: "En die Heilige Gees was op Simeon." Dit was God die Vader wat Simeon vanuit sy genadetroon deur die Heilige Gees aangespoor het en in sy sondeverlorenheid na die profetiese Geskrifte gedryf het. En daar - in die profetiese Geskrifte - het Simeon gelees van die heerlikheid van Christus en van die magtige vertroosting van sy leer. En deur daardie selfde pro- 
fetiese Skrifte het die Vader Simeon aangespoor om die dag van die koms van sy Seun in die vlees te begeer.

Waarom het die Jode nie geglo dat Jesus die Messias van die Skrifte is nie? Stefanus lê sy vinger op die wond wanneer hy in sy preek in Handelinge 7 sê: "Julle hardnekkiges, julle weerstaan altyd die Heilige Gees (v. 51)". En dan gaan Lukas verder:

Stefanus het die oë na die hemel gehou en die heerlikheid van God gesien en Jesus wat staan aan die regterhand van God. En Stefanus het gesê: Kyk, ek sien die hemele geopend en die Seun van die mens aan die regterhand van God staan (vv. 55-56).

Ons kan maar sê Stefanus kyk in die hemel in en hy sien die OuTestamentiese Psalm 110. Met sy oë aanskou hy die vervulling van daardie Messiaanse Psalm: Jesus aan die regterhand van God. Hoe sien hy dit? Lukas onthul die geheim. Stefanus was vol van die Heilige Gees en het gesien.

Simeon sien en Stefanus sien. Beide van hulle sien op dieselfde manier: alleen deur die Heilige Gees. Beide sien dieselfde: hulle sien die Ou Testament in sy betroubaarheid en in sy vervulling. Hulle sien die inhoud van die Ou Testament, naamlik Christus. Simeon hou die beloofde Christus in sy hande, Stefanus gee homself oor in die hande van die Vors van die OuTestamentiese Psalm 110.

Hier is geen sprake van interpretasie of akkommodasie nie, maar van sien. My oё het u heil gesien.

\subsubsection{Wat Moses en die Profete vir Jesus Christus in die tyd van sy aardse omwandelinge was}

In hierdie verband word net wat Kohlbrugge (1855:66) skryf oor Jesus se verskyning aan die Emmausgangers (Luk. 24) uitgelig. Kohlbrugge skryf dat dit vir Jesus maklik sou gewees het om Homself aan die twee Emmausgangers bekend te maak. Dit doen Hy egter nie. Hy begin deur uit Moses en die Profete aan hulle te leer wat met Hom moes gebeur. Agter hierdie optrede van Jesus sien Kohlbrugge iets heel besonders. Die besondere lê daarin dat Jesus op 'n verhewe manier die Skrifte, die Ou Testament, handhaaf. Jesus wil nie hê dat die Emmausgangers aan 'n verskyning moet glo nie. Jesus wil hê dat hulle aan die geskrewe Woord van die "Ou Testament" sal glo. Voordat Hy Hom dus aan hulle bekendmaak, sê Hy vir hulle: "O onverstandiges en trages van hart om te vertrou." Om te vertrou waarop? Op Hom, op Jesus? Nee, - maar traag om te vertrou op alles wat die Profete gespreek het. "Moes die Christus nie al hierdie dinge gely het en ingegaan het in sy heer- 
likheid nie?" En dan begin Jesus van Moses en van die Profete af om vir hulle dit uit te lê wat van Hom in al die Skrifte geskrywe was.

"Trages van hart om te glo alles wat die Profete gespreek het". Kohlbrugge (1888:54) het ook in 'n preek op hierdie woorde ingegaan: "Sien julle, sê hy vir sy gemeente, sien julle dat die Here Jesus wil hê dat die Profete geëer moet word?” En dan gee Kohlbrugge ook die rede daarvoor:

Want in die Profete is Jesus self aan die Woord - daarom. Die Profete het nie met hulle eie gedagtes gekom nie, maar hulle is gedra deur die Gees van Christus. Jesus wil hê dat die Profete geëer moet word en - Hy het dit self ook gedoen, nie alleen na sy opstanding nie, maar ook voor sy dood. Want in Getsemane het Hy nog gesế: "Hoe sou dan die Skrifte van die Profete vervul word, wat sê dat dit so moet gebeur?” (Mat. 26:54). En ook aan die kruis het Hy Hom in alles wat Hy gesê en gedoen het, slegs deur die Profete laat lei, soos Johannes 19:28 ook sê: "Omdat Hy geweet het dat alles al volbring was - sodat die Skrif vervul sou word - het Jesus gesê: Ek het dors!" (Kohlbrugge 1888:54-55).

Dat Jesus Moses en die Profete ten hoogste geëer het, dat Hy uit die Ou Testament geleef en gespreek het, dat Hy Hom voortdurend daaraan vasgeklem het en daarin geglo het en Hom daardeur alleen laat lei het - dit is 'n gedagte wat soos 'n goue draad deur al Kohlbrugge se werke loop. Ons kan beslis hier praat van 'n besondere lyn in sy teologie. Met woord en daad, met sy leer en met die daad van sy sterwe en die daad van sy opstanding, met sy vervulling van die Skrifte, het Jesus die Skrifte gehandhaaf en bekragtig as die betroubare, gesagvolle, troosryke Woord van God (Kohlbrugge 1888: 67). Jesus wil die Emmausgangers in die profetiese Woord inlei. Daarin en daaruit moet hulle die ware, lewende Christus leer ken (Kohlbrugge 1888:55).

As 'n mens dit alles hoor, dan word duidelik presies wat Kohlbrugge se vader bedoel het toe hy gesê het: "Moses is die beste man om ons in te bring en rond te lei in ons Koning se paleis." En: "As jy die vyf boeke van Moses verstaan, verstaan jy die hele Skrif."

\subsection{Die slot van die boek}

Kohlbrugge (1855:133) het nie verwag dat hy die aan nuwerwetse geleerdes voldoening sou verskaf met hierdie boek nie. Wel voel hy dat hy sy doel bereik het. Daardie doel was om elke denkende gemoed te oortuig dat die boeke van Moses en die Profete nie "oud" is vir al die aangehaalde getuies uit die Nuwe Testament nie. Inteendeel, dit was vir hulle juis die enigste gesaghebbende voorskrif vir leer en lewe, die Heilige Skrif waaruit hulle die 
evangelie van die Koninkryk van God onderrig het. Dit was nie vir hulle "oud" nie. Hulle het Christus daarin gevind.

Kohlbrugge (1855e:134-135) kan aan die einde van sy boek net tot een gevolgtrekking kom: Óf die Here, sy apostels en die eerste Christene het die Skrifte van Moses en die Profete heeltemal verkeerd uitgelê, hetsy dan omdat hulle dit nie verstaan het nie, hetsy dan omdat hulle ander bedrieg het - óf ons moet eenvoudig hierdie Skrifte so verstaan en uitlê soos hulle, sonder om iets daarvan weg te neem of daaraan toe te voeg. Hier is geen middeweg nie.

\section{AKTUALITEIT}

Is Kohlbrugge nog aktueel vir vandag?

Net enkele hedendaagse teoloë word aangehaal, om te laat sien hoe aktueel hy wel is.

- In 'n resensie van die boek van Adrio König Die helfte is my nooit oor Jesus vertel nie: 'n Nuwe kyk op Een wat jou lewe verander skryf prof. Sakkie Spangenberg: "Jesus word nie in die Ou Testament voorspel nie!" (http:// www.nuwe-hervorming.org.za/files/bk-4.html\#Konig).

- Jasper Burden skryf in Bybel in Praktyk (1997) by Psalm 2:

Ons moet nie in die Messiaanse Psalms dadelik 'n voorspelling van Christus sien nie, maar weet dat dit 'n latere interpretasie is van die eerste Christene waarin ons vandag natuurlik mag deel.

By Psalm 110 sê hy:

Ons kan nie uit die Messiaanse Psalms direkte voorspellings oor Christus aflees nie. Ons moet die Psalmbundel as 'n voor-Christelike boek lees.

- In Bybellennium (Vosloo \& Van Rensburg 2000) word by Psalm 110 verklaar:

In die Nuwe-Testamentiese tyd het Christus 'n derde interpretasie aan die Psalm geheg. Hy het die Psalm se uitsprake oor die Messias en die Priester-koning op Homself van toepassing gemaak.

- In 'n onderhoud met Psalm-omdigter T.T. Cloete in Rapport (4 November 2001) word berig:

Daar was die dominee wat hom (Cloete) kom spreek het oor Messiaanse verwysings in sekere Psalms wat nou op grond van nuwe navorsing verwyder is. 
In die Algemene Kerkbode van 11-13 April 2002 skryf Cloete:

Ps. 110 is onder meer volgens my teologiese adviseurs, volgens die Nuwe Vertaling van die Bybel, volgens die "nieuwe berijming" en volgens Bonaventura Hinwood se omdigting in Afrikaans vir die Katolieke Kerk, nie 'n Messiaanse Psalm nie.

Kommentaar is, in die lig van wat reeds gesê is, oorbodig.

\section{TEN SLOTTE}

In 'n gedig Op de moderne wetenschap die de wonderen en de opstanding loochent, geskryf in Januarie 1862, hekel Kohlbrugge (Groot 1953:112) die moderne teologie:

Moderne wetenschap! Help van den dood!

Daar ligt u leerling in zijn laasten nood!

"Een drankje van kritiek en pleisters van legende!"

Hebt ge anders niet! Waarheen zich nu te wenden?

\section{BIBLIOGRAFIE}

\section{BURDEN J}

1997. Psalms. In: W. Vosloo \& J.J.J. van Rensburg (reds.), Die Bybel in Praktyk (Nuwe Vertaling). Vereeniging: Christelike Uitgewersmaatskappy. (Elektroniese uitgawe.)

\section{DONKERSLOOT P M}

1962. De goddeloze gerechtvaardigd. Utrecht: De Banier.

\section{EDELKOORT A H}

1941. De Christus-verwachting in het Oude Testament. Wageningen: H.Veenman \& Zonen.

\section{GroOt K}

1953. Koblbrugge in en uit zijn gedichten. Wageningen: H.Veenman \& Zonen.

\section{Hengstenberg E W}

1973. Christology of the Old Testament. Grand Rapids, Michigan: Kregel Publications. 


\section{KOHLBRUGGE H F}

1855[1846]. Wozu das alte Testament? Anleitung zur richtigen Schätzung der Bücher Mosis und der Propheten. Elberfeld: Verlag der niederl.-reform. Gemeinde.

1884. Zwanzig Predigten im Jahre 1846 gehalten. Elberfeld: H.W. Kaufmann. 1888[oorspronklike datum onbekend]. Feeststoffen. Leerredenen gehouden door Dr. H.F. Koblbrügge, in leven predikant bij de Nederlandsch-Gereformeerde Gemeente te Elberfeld. Uit het Hoogduitsch. Tweede herziene uitgave. II. Paaschpreeken. Amsterdam: Scheffer \& Co.

1889. Ansprache des Herrn Pastor Kohlbrügge an die Jugend der Gemeinde bei seinem Jubiläum 1871 Juni. In: H.F. Kohlbrugge, Zur Feier des fünfundzwanzigjährigen Bestehens unsers Vereins (Elberfeld: Festgabe des Vorstandes der Gesellschaft "Vereinigung"), pp. 5-13.

1988[1855]. Waartoe het Oude Testament? Kampen: Uitgeverij De Groot Goudriaan. (Derde druk.)

1989[1833]. Het lidmaatschap bij de Hervormde Gemeente bier te lande mij wille-keurig belet. Echte bescheiden van H.F. Koblbrugge. Met een inleiding van Dr. J. van Oort. Leiden: J.J. Groen en Zoon.

1992a. Twaalf twaalftallen leerredenen in nagenoeg chronologische volgorde. Derde, ongewijzigde druk van de niemwe en van aantekeningen voorziene uitgave (1910-1917). Eerste en tweede twaalftal gehouden in 1833 en 1846. Houten: Den Hertog.

$1992 \mathrm{~b}$. Twaalf twaalftallen leerredenen in nagenoeg chronologische volgorde. Derde, ongewijzigde druk van de nieuwe en van aantekeningen voorziene uitgave (1910-1917). Sevende en achtste twaalftal gehouden in 1848 en 1849. Houten: Den Hertog.

1995[1829]. Specimen Philologico-Theologicum Inaugurale, exhibens Commentarium in Psalmum Quadragesimum Quintum. Vertaald uit het Latijn door C. van Ginkel. Utrecht: De Banier.

\section{OTTEN W}

1992. Uit het levensboek van Dr. H.F. Koblbrugge. Houten: Den Hertog.

\section{VAN LONKHUIJZEN J}

1905. H.F. Koblbrugge, zijn prediking in de lijst van zijne tijd. Wageningen: Naamloze Vennootschap Drukkerij "Vada".

\section{VAN WIJK P}

1985. Koblbrugge's proefschrift over Psalm 45. Een onderzoek naar de theologische positie. Utrecht: R.U. (Ongepubliseerde skripsie.)

\section{Vosloo W \& VAn Rensburg J J J}

1997 (c.1993). Die Bybel in Praktyk (Nuwe Vertaling). Vereeniging: Christelike Uitgewersmaatskappy. (Elektroniese uitgawe)

2000 (c.1999). Die Bybellennium eenvolumekommentaar: Die Bybel uitgelê vir eietydse toepassing. Vereeniging: Christelike Uitgewersmaatskappy. (Elektroniese uitgawe.)

\section{WICHELHAUS J}

1857. Vorbericht. In: H.F. Kohlbrugge, Zwanzig Predigten gehalten im Jahre 1846. Elberfeld: H.W. Kaufmann. 
Acta Theologica Supplementum 5

Trefwoorde

Keywords

Kohlbrugge

Kohlbrugge

Ou Testament

Old Testament

Christus en die Ou Testament

Christ and the Old Testament

Gesag van die Bybel

Authority of the Bible

Hermeneutiek

Hermeneutics

Messiaans

Messianic 